COBISS: 1.01

\title{
THE UNDERGROUND POST OFFICES IN POSTOJNSKA JAMA, SLOVENIA, 1899 - 1945
}

\author{
PODZEMNA POŠTNA URADA V POSTOJNSKI JAMI \\ SLOVENIJA, 1899 - 1945
}

TREVOR R. SHAW ${ }^{1} \&$ ALENKA ČUK ${ }^{2}$

${ }^{1}$ Karst Research Institute, ZRC SAZU, Titov trg 2, SI-6230 POSTOJNA, SLOVENIA e-mail: izrk@zrc-sazu.si

${ }^{2}$ Notranjski muzej Postojna, Ljubljanska cesta 10, SI-6230 POSTOJNA, SLOVENIA e-mail: alenka.cuk@studioproteus.si 


\begin{abstract}
UDC: 725.16(497.4)(091)

Trevor R. Shaw \& Alenka Čuk: The underground post offices of Postojnska jama, Slovenia, 1899 1945
\end{abstract}

The only cave post offices to have been situated underground were in Postojnska jama. In 1899 the cave management, responding to the growing use of picture postcards, built a stone post office near Kongresna dvorana $500 \mathrm{~m}$ from the entrance. It was open by 15 August 1899, with a special "Adelsberger Grotte / Postojnska jama" cancellation authorised by the postal authorities. This building remained in use until 1927 (with the Italian "Postumia (Grotte)" postmark after 1922), when it was replaced by a new building 1,4 km inside the cave. Its last recorded use was 15 August 1945 when the cave was reopened under Jugoslav management.

Key words: caves, Slovenia, Postojnska jama, post offices, philately.

\title{
Izvleček
}

UDK: 725.16(497.4)(091)

\section{Trevor R. Shaw \& Alenka Čuk: Podzemna poštna urada v Postojnski jami, Slovenija, 1899 - 1945}

Edina poštna urada, ki sta delovala v podzemlju, sta bila urada v Postojnski jami. Leta 1899 je jamska uprava, število prodanih razglednic je v tem času močno naraslo, nedaleč od Kongresne dvorane oziroma $500 \mathrm{~m}$ od vhoda zgradila podzemni poštni urad. Odprt je bil 15. avgusta 1899, poštne oblasti pa so dovolile uporabo posebnega poštnega žiga ("Adelsberger Grotte / Postojnska jama”). Ta urad je posloval do leta 1927 (z italijanskim žigom "Postumia (Grotte)" po letu 1922), nakar ga je nadomestil nov poštni urad, skoraj kilometer in pol oddaljen od vhoda. Urad je zadnjič posloval 15. avgusta 1945, ko je bila Postojnska jama po končani drugi svetovni vojni ponovno odprta.

Ključne besede: jame, Slovenija, Postojnska jama, poštni uradi, filatelija. 
Postojnska jama is unique in having had a proper official post office (indeed two at one time) deep underground, selling stamps and picture postcards and accepting them for despatch. A succession of authorised special postmarks for the cave bear dates from 1899 to 1945. The post office was included in the Universal Postal Union's list of world post offices (Union Postale Universelle 1937), though not in all the relevant editions, and in the Austrian Postamts Verzeichnis from 1901. The first building, erected in 1899, remained in use until about 1927, when another was opened even further inside the cave.

Elsewhere in the world other post offices have had cave names in their postmarks, but none has been sited underground. Thus the Jenolan Caves post office in Australia, opened in 1898, was in a building outside the caves, as were those of Mammoth Cave (Kentucky) and Dobšinska jaskyn̆a (Slovakia), while Weyers Cave (Virginia) and Wookey Hole (England) were the names of the settlements containing those caves. Some tourist caves, such as Carlsbad Caverns (New Mexico), have unofficial post boxes in which mail marked with a special cave handstamp can be posted but it has then to be taken to the local post office for cancellation and despatch.

The post office archives for this part of Slovenia, which was successively in Austria and then a part of Italy between 1900 and 1939, were little accessible to us. Our information has therefore been derived mainly from the archives of Postojnska jama and from contemporary books and newspapers, together with some evidence from dated postmarks. The only problems resulting from this limitation have been uncertainty about the exact dates of the opening and closing of the post offices themselves and of the use of the special postmarks.

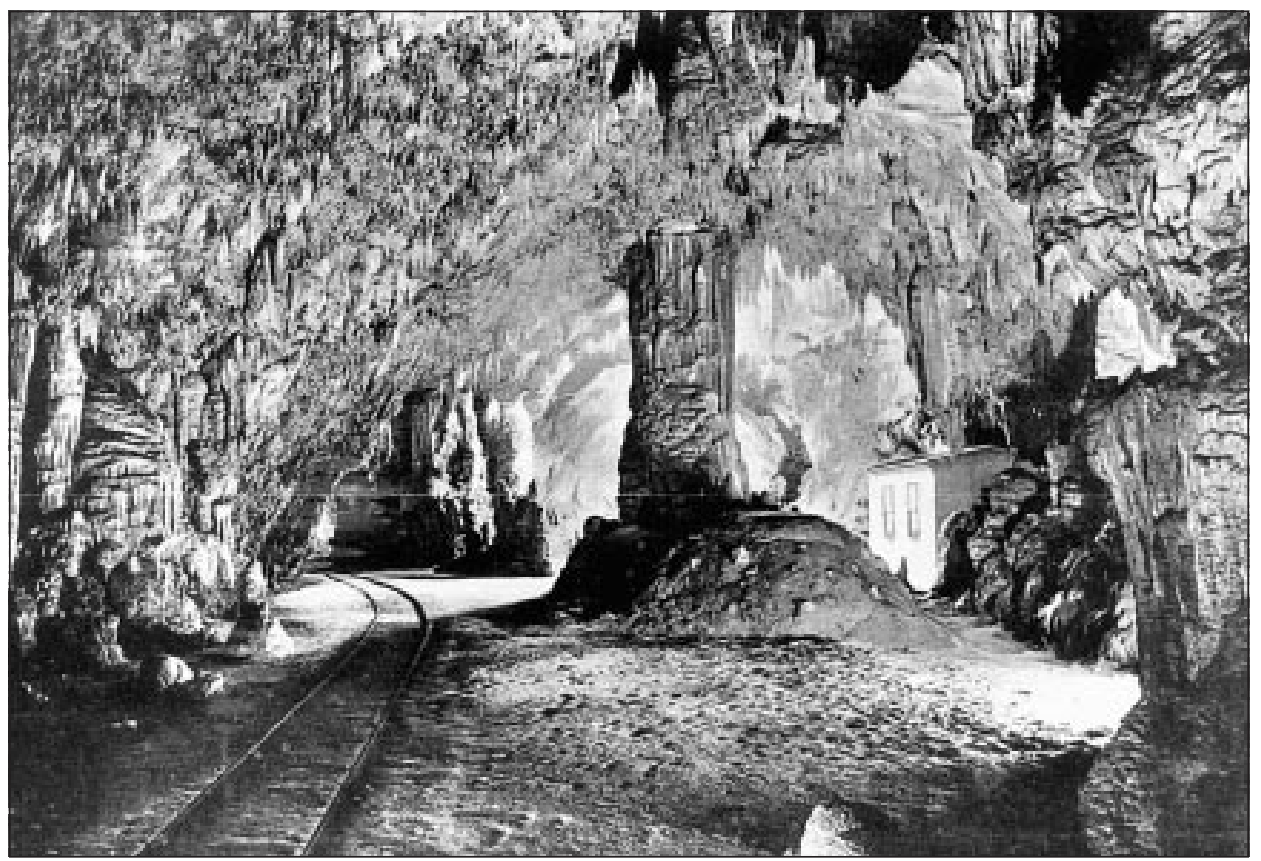

Fig. 1: The post office opened in 1899 near Kongresna dvorana. A photograph taken by Maks Šeber not later than 1908. 
It was the widespread and increasing use of picture postcards that led to the creation of a post office inside the cave. The very first picture postcards had been produced in Germany in the 1870s, the earliest known cave postcard was used in May 1890 (Holzmann et al. 1992, 21) and a picture postcard of Postojnska jama (now in the Notranjski muzej in Postojna) was received in Wien on 27 August 1891. Sending such postcards became more and more popular throughout the 1890 s and the building of the underground post office was very timely.

\section{THE AUSTRIAN POST OFFICE}

In 1899 the Austrian Ministry of Commerce agreed to the cave management's proposal to build and operate a post office in the cave. Its customers would be only the visitors there, either normal tourists or those attending the special twice-yearly festivals (Grottenfests) held in the

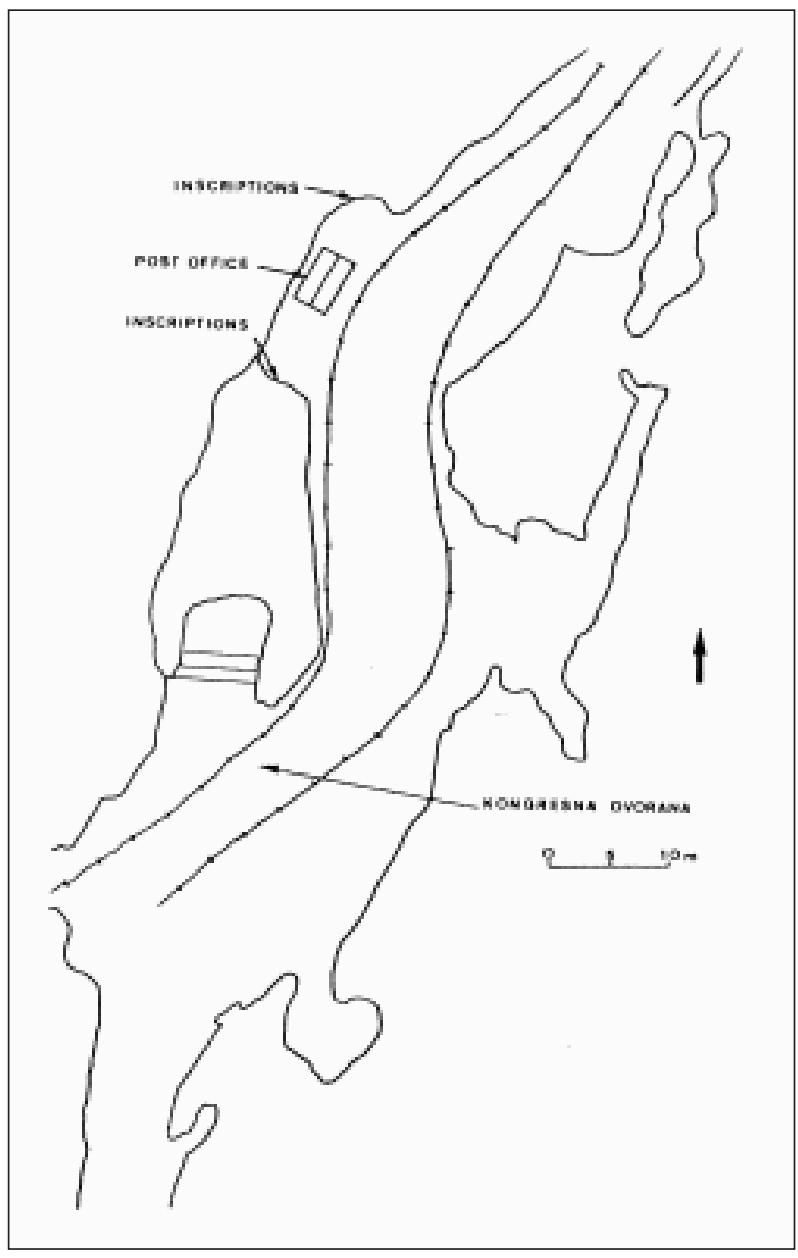

Tanzsaal (now Kongresna dvorana) (Lapajne 1907, 49).

The building itself (Fig. 1) was of stone, about $4 \mathrm{~m}$ long by $2 \mathrm{~m}$ wide, with a low-pitched roof. There was a door at the north end and two window openings as sales counters. It was built against the west wall of the main passage (Fig. 2), $35 \mathrm{~m}$ beyond the far end of Kongresna dvorana where the dancing took place, and about $500 \mathrm{~m}$ from the cave entrance (Fig. 3).

Fig. 2: Site of the post office opened in 1899. Redrawn from a survey of c.1927-34, with the building located according to marks remaining on the cave wall. The lines of the present railway have been sketched in approximately. 


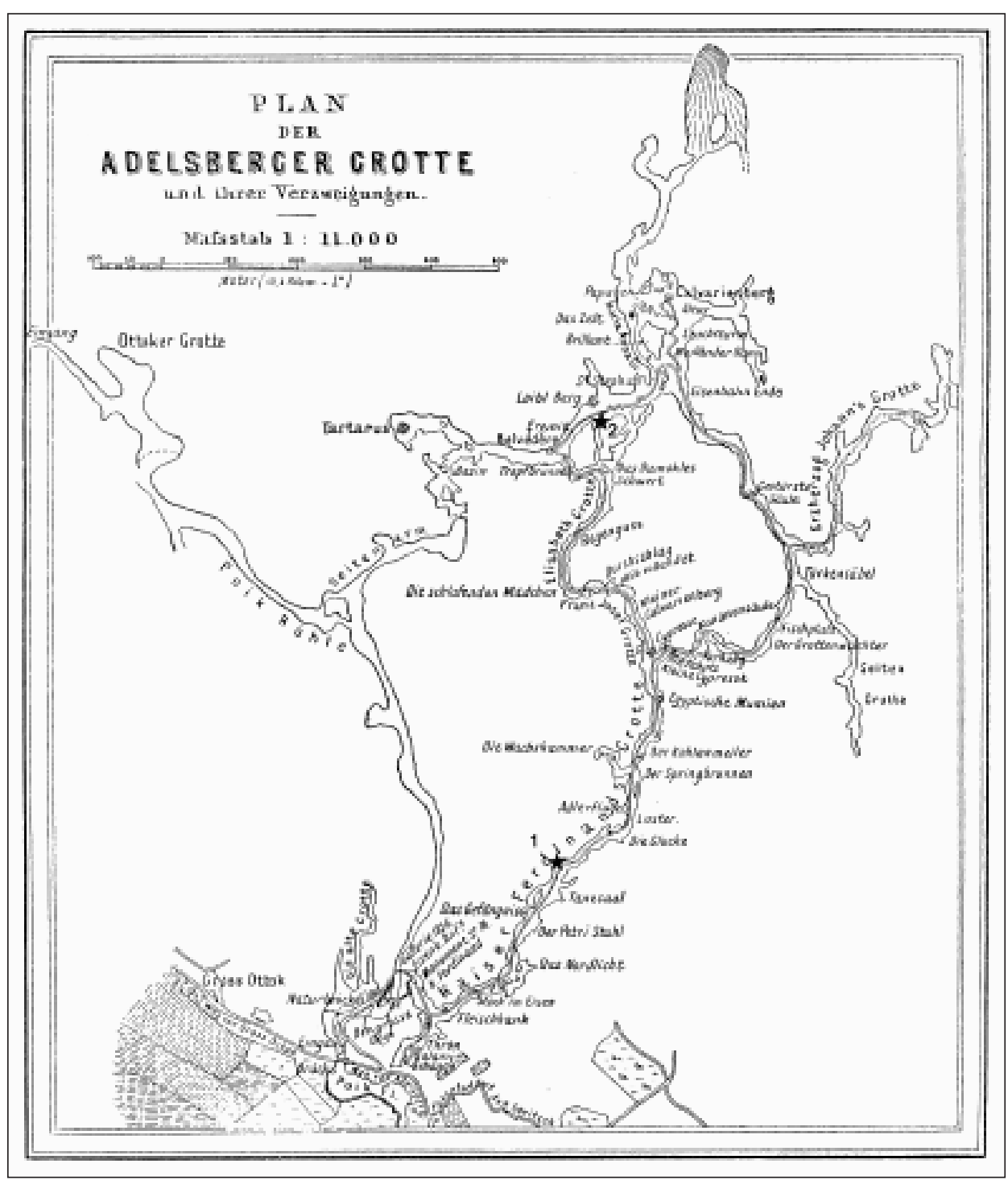

Fig. 3: The positions of both post offices added to a cave plan published by Putick (1897).

The post office was certainly in use at the traditional Grottenfest of 15 August 1899. A cave postmark with that days' date (Fig. 4) is known but none earlier than that. Although it is possible that the office was open before the Grottenfest it is most likely that its inauguration was on that special occasion rather than on an ordinary day when there might have been no visitors at all, or only a few tens at most. 


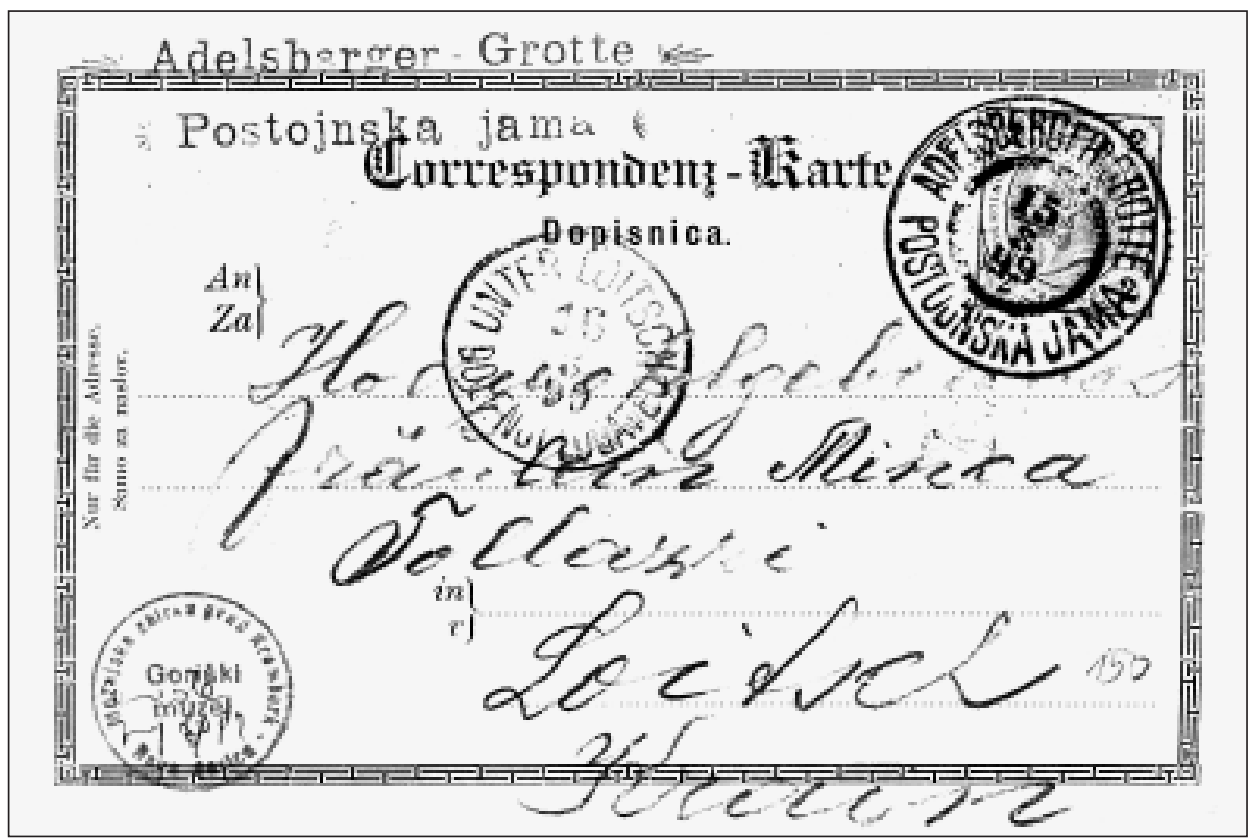

Fig. 4: Cave postmark dated 15 August 1899, the earliest known. This is the date of the summer Grottenfest, which is almost certainly when the post office first opened.

As will be seen in Fig. 4, the postcard used on 15 August 1899 had on it also a special rubber stamp "Adelsberger - Grotte / Postojnska jama" in the top left-hand corner. The decorative marks at both ends of this show that these were not just typewritten words. The same rubber stamp was used two months earlier, on 15 June, on a postcard in the Notranjski muzej collection but the postmark there was the ordinary "Adelsberg / Postojna" town postmark and not the special cave on. Whether the rubber stamp was applied outside the cave that time, or postcards were already sold at the underground post office before it had its own new postmark is not known.

This post office was operating again in the next Grottenfest, the traditional one on Whit Monday (Pentecost), for a cave postmark dated 6 June 1900 also exists (Holzmann et al. 1992, 55). The Laibacher Zeitung newspaper (Anon. 1900) reported that nearly 3000 people came on that occasion to enjoy the music and dancing and "a field [ambulante] post office was set up in the Tanzsaal...; no fewer than 7000 picture postcards were sold and sent to all destinations."

The post office was probably open also on normal days during the tourist season, for many postmarks are known with dates that are not those of the Grottenfest. It was certainly open, by special permission of the Ministry of Commerce, on five other occasions besides Whit Monday (Anon. 1905, 7). In later years a letter box was available even when the office was closed. It is visible in the photograph of 1911 (Fig. 5) though not on the earlier one (Fig. 1). A total of 47 postmarks between 1899 and 1918 have been examined and of these 16 bore Grottenfest dates; i.e. $34 \%$ were posted on two days of the year, and $66 \%$ on some of the remaining 363 days. It is noticeable that the total number seen was markedly greater from 1912 onwards when a letter box 


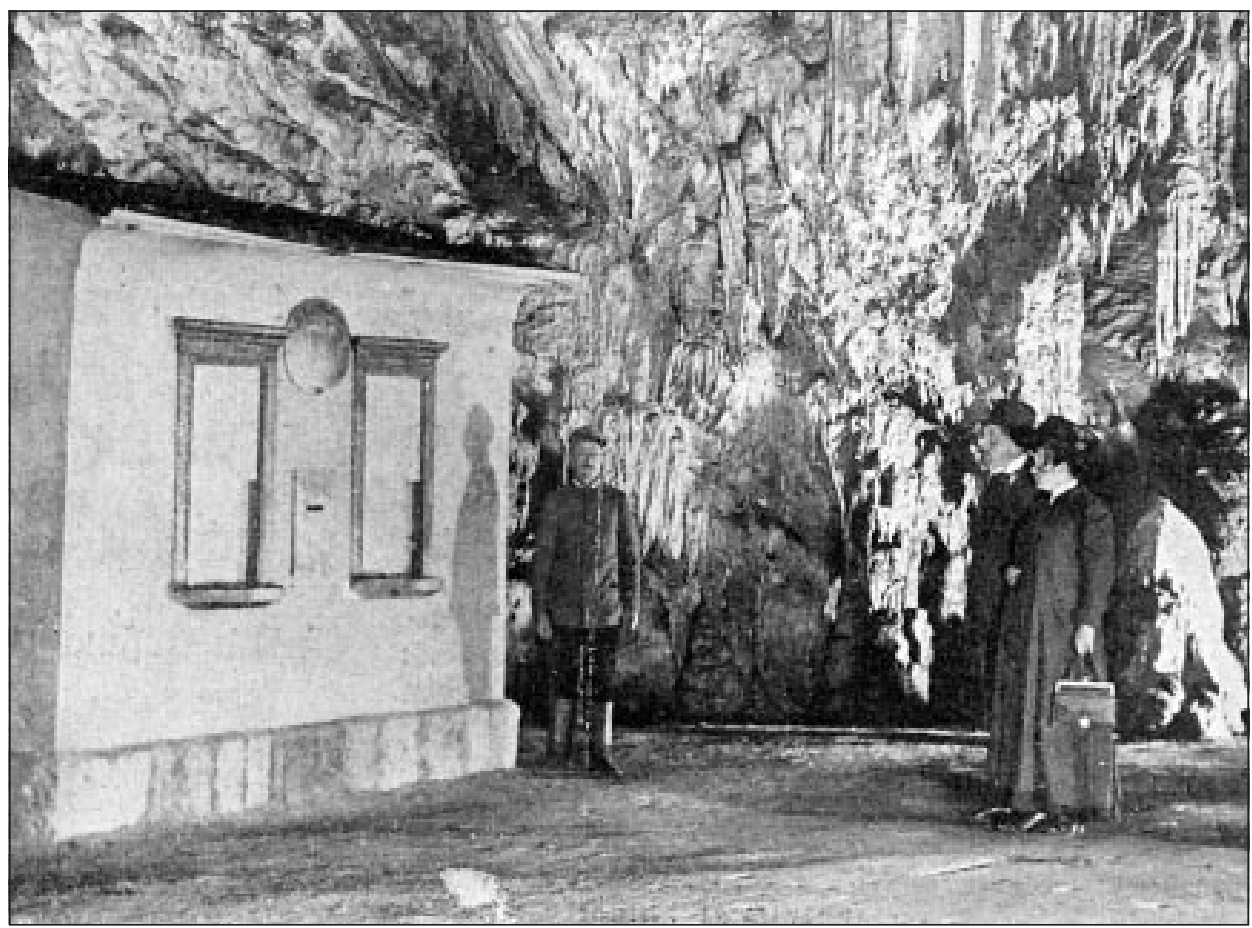

Fig. 5: The post office in 1911, showing a letter box between the two windows (Anon. 1911a).

is known to have existed and the visitor numbers also began to increase. By that year, too, the postal authorities allowed the special postmarks to be used throughout the season from 1 March to 1 November (Adelsberg 1912, 6). In 1910 Juvanec $(1910,31)$ reported that there were tables and seats outside the building for visitors to write their postcards on, like those later ones seen in Fig. 10.

The number of postcards posted at the first 1900 Grottenfest has already been noted as 7000 . Sales figures were published also for later years: 13.800 in 3 hours on Whit Monday 1904 (Lapajne 1907, 49); 37.000 from 12.000 people on Whit Monday 1909 (Perko 1910, 31); 75.000 on Whit Monday 1911 (Anon. 1911b); and 47.800 (weighing $219 \mathrm{~kg}$ ) in the 4 hours of the Grottenfest in August 1911 (Anon. 1911c). In 1911 it was also reported that a daily average of from 6000 to 10.000 postcards were sent, presumably in the season only (Anon. 1911a).

The presence of this unique underground post office in the cave provided a splendid opportunity for international publicity. The cave archives contain few newspaper cuttings of any sort in the early years of the century, but after Giovanni Andrea Perko became director in 1909 extensive collections were kept. He was very conscious of the power of publicity, writing many popular articles himself for publication throughout Europe; his bibliography (Novak 1988, 134-138) records 182 of these between 1894 and 1936. It was under his direction that post office publicity really took off in 1911. One press release appeared in at least 18 newspapers in what are now four different countries (France, Germany and the Czech Republic, as well as Austria); another was in 


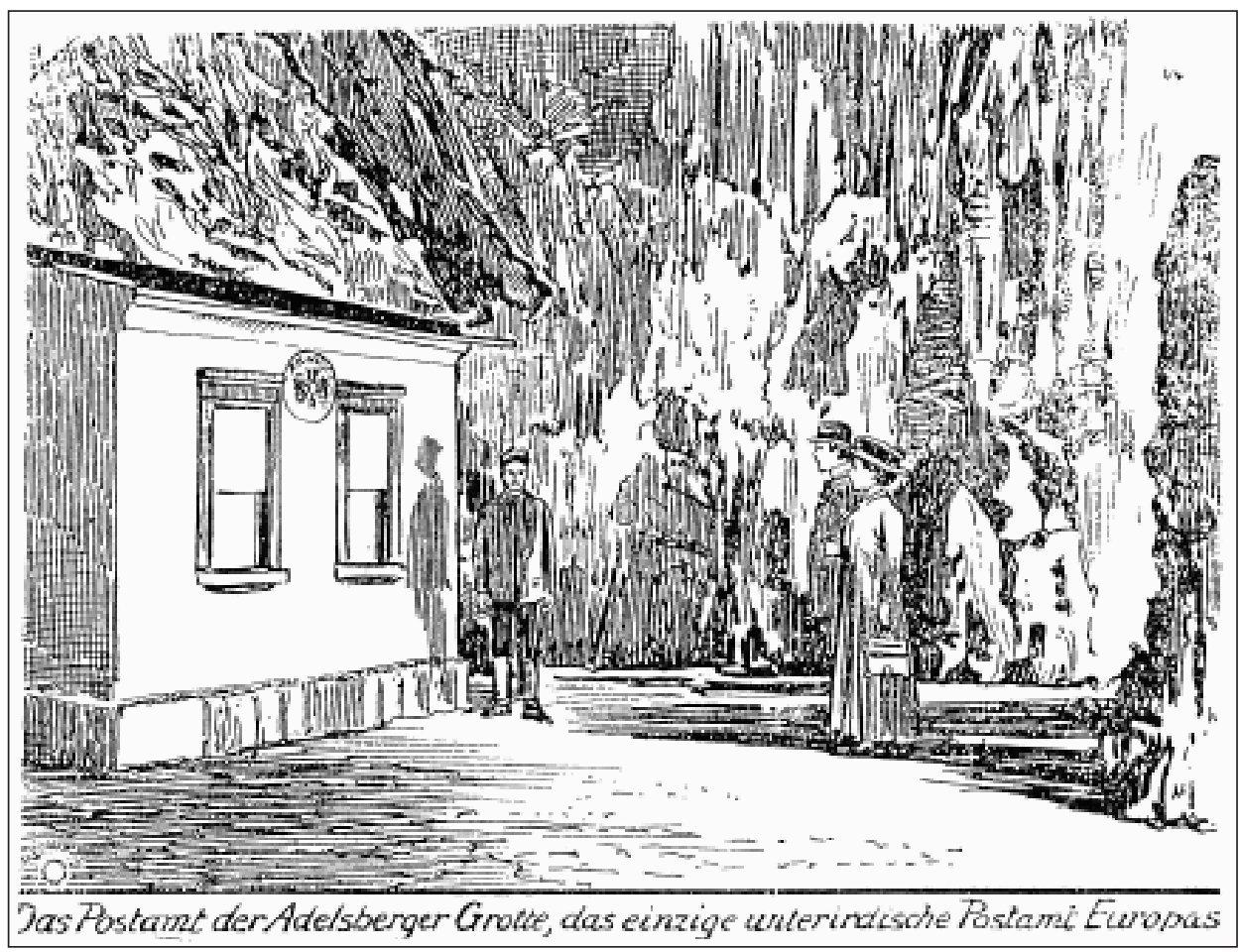

Fig. 6: A drawing based on the 1911 photograph and used for publicity (Anon. 1911d).

12 newspapers. Variants of the drawing reproduced in Fig. 6, were published in 22 newspapers in three countries. These numbers are probably reasonably complete as they are based on the caves' own collection of press cuttings.

At Christmas 1915 two special military field post office postmarks were used, presumably at the underground post office - "K. u. k. Grottenfeldpostamt 81. Kriegsweihnachten 1915." (Imperial and Royal Cave Field Post Office 81. War Christmas 1915.) and another rather similar one (Fig. 7) (Rainer 1995, 81, 104). All field post offices were numbered and, although their locations

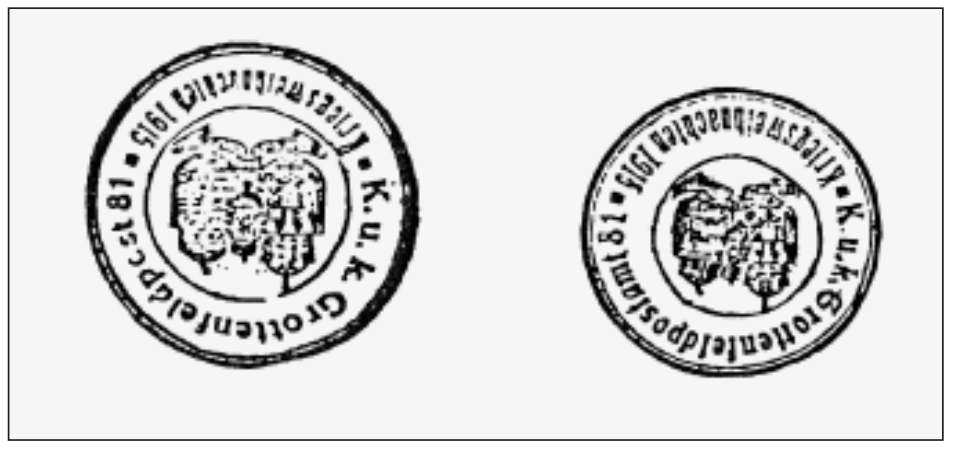

Fig. 7: Austrian army field post office postmarks for the cave at Christmas 1915 (Rainer 1995, 81). 
were not fixed, number 81 was at Postojna in 1915 and 1916, using field postmarks of the usual type. Just why these special Christmas postmarks were made is not known. War is mostly waiting and it is probable that the Austrian troops stationed in the Postojna area celebrated Christmas by having music and dancing in the Tanzsaal and reviving the traditional cave post office.

\section{THE AUSTRIAN POST OFFICE BUILDING AFTER WORLD WAR I}

At the end of World War I a part of the former Austrian province of Krain which is now in western Slovenia was ceded to Italy by the Treaty of Rapallo. The border between the Italian region and what was to become Jugoslavia lay between Postojna and Planina, so the former

\section{Grotte di Postumia}

\section{Domenica 17 Settembre 1922

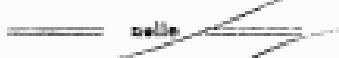 \\ Girotte di Postumia sfarzosamente illuminate con criteri artistici \\ Grande Festa Pubblica}

Balle - Bande - Luminarie - Servinto

di Risterante - K. R. Poste ecc, ece.

TUTTO SOTTOTBRRA = $30 \%$ DI RIBASSO ANCII PER I TRENI NORMLLI

\section{Orapio dei Treni speciali UDINE-TRIESTE-HOSTUMIA}
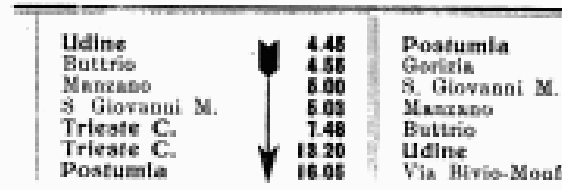

21.00
0.04
0.45
0.51
0.59
1.12

\section{CON QUALUNQUE TEMPO:}

Biglietrl dt passagglo in vendita dal 10 settembre presso I'Agenzla Cavallero, Plazza del Duomo $e$ presso le Stazlonl ferrovlarle.

NB. L'orarlo del treno permette una sosta a Trieste sufflelente alla visita della FIERA CAMPIONARIA.
Adelsberg Cave came under Italian control and was called Postumia Grotte. As an asset to Italian tourism it continued to be well managed under the direction of the same G. A. Perko, who changed the spelling of his name to Perco to Italianise it.

Delays caused by the administrative change of state ownership from one country to another, in addition to recovery from war on the not so distant Soča / Isonzo front, meant that Postojnska jama was not fully reopened early in 1922. "There will be no Whitsun festival this year because Postojnska jama is not yet renovated. Visits will be pos-

Fig. 8: A poster for the first cave festival after World War I showing that the post office (" $R$. $R$. Poste") will be open. 


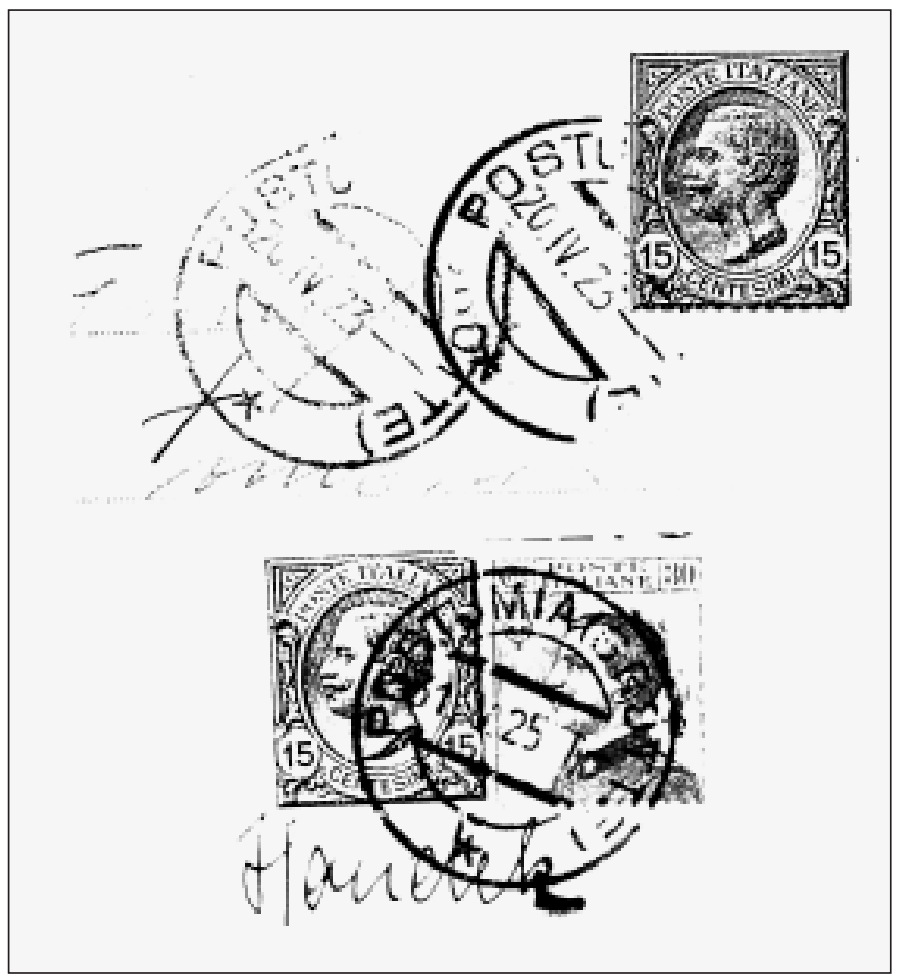

Fig. 9: The earliest Italian postmark known for the cave (20 April 1923), together with a better example of later date (28 mm diam.).

sible but only like on ordinary days [without music and dancing]" (Anon. 1922a). The post office must have been revived between then and 17 September 1922, the official reopening of the cave (Anon. 1922b) at the traditional autumn festival, for an advertising poster (Fig. 8) in the Postojnska jama archives announces "marvellous electric lighting with 300.000 candles, dancing, restaurant, post office, music, ... all underground.” The date of the earliest post-war cave postmark seen (Fig. 9) is 20 April 1923. That was a whole month before the Whitsun festival when "the post office in the Ball Room worked for seven hours without stopping and sold 20.000 stamps" (Anon. 1923a). At the autumn festival of 1923 "the underground restaurant and post office will operate between 13.00 and 20.00" (Anon. 1923b).

A guidebook of 1924 indicates how the old post office near Kongresna dvorana functioned at that time (Fig. 10). It was open only during the traditional cave festivals, but postcards put in the letter box there on any day were despatched with the special "Postumia (Grotte)" postmark. "Many tables provided for writing them on are occupied by hundreds of people every day who hurry, during their ten-minute stop there, to write many postcards which they can buy at a nearly counter" (Perko \& Gradenigo 1924, 114). The post office had been repaired in the first half of 1924 , and soon afterwards roofs were erected over the five tables used by visitors to shelter them from the drips that occurred after long rain (Anon. 1925, 14). There were four clerks working in the post office (Urbani 1925, 5), who would have been selling postcards as well as stamps.

"During the cave festas some 30.000 are normally posted" (Perko \& Gradenigo 1924, 114). At the Whitsun festival of 192425.000 are reported to have been posted in 6 hours (Anon. 1924a) and 78.000 were sent during the one in August (Anon. 1924b). At Whitsun 192652.487 were despatched (Anon. 1926a); another newspaper (Anon. 1926b) reports a total of 800.000 postcards posted each year and cancelled with the special cave postmark. 


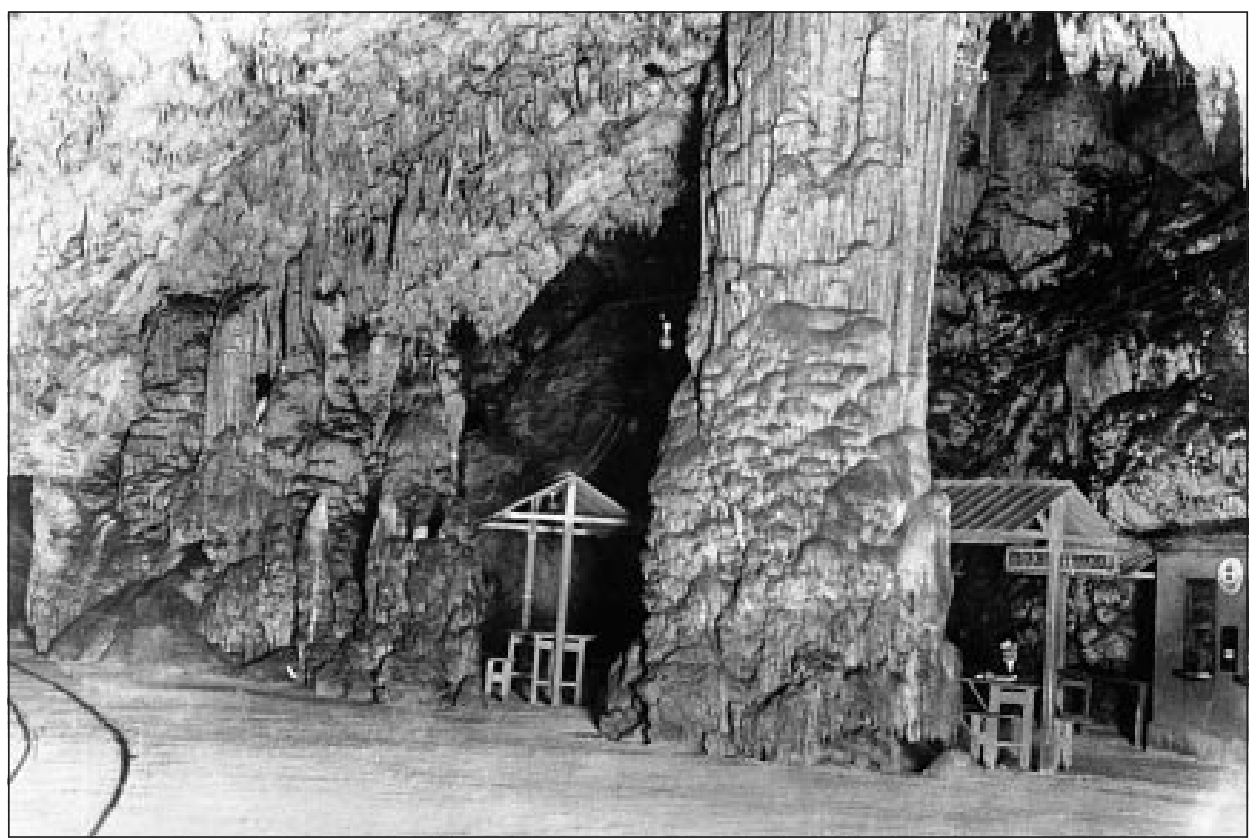

Fig. 10: The old post office of 1899 in use about 1924, with a notice advertising stamps and postcards for sale and with tables for writing them on.

The "POSTUMIA (GROTTE)*" postmark used at the time (Fig. 9), $28 \mathrm{~mm}$ in diameter to distinguish it from a later version, has been seen with dates from 1923 to 1926. Another of the same size lettered "POSTUMIA GROTTE * TRIESTE *" (Fig. 11) came into use in 1927, as a result of political reorganization and has nothing to do with the opening of the new post office building in Koncertna dvorana in that year. Of the 27 examples seen of these two postmarks, only three $(11 \%)$ were dated on festival days, and the cave visitors' book shows many more individual tourists or parties visiting on non-festival days than in the past.

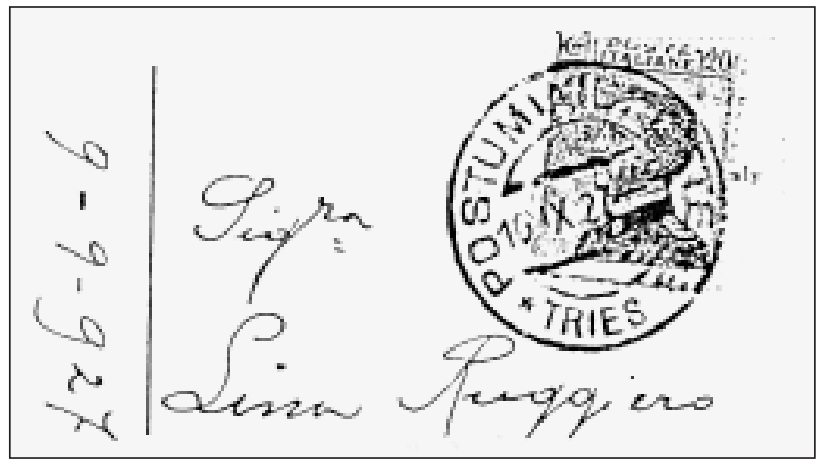

Fig. 11: A new cave postmark used on 10 September 1927 (28 mm diam.) (Banti 2001). 
A further indication of the continued use of the Austrian building after 1924 is provided by names and dates pencilled on the rock walls close to where the building stood. Some $6 \mathrm{~m}$ south of it (see Fig. 2) are three dated 1925 and seven of 1926, while close to it to the north are two of 1925 and four of 1926, besides many others which are illegible. It seems that people in the queues for the two windows occupied their time thus.

Just when this old Austrian post office ceased to be used in Italian times is not known exactly. A large newly built post office was opened in Koncertna dvorana early in 1927, as will be seen, but the earlier building was used concurrently with it for a time. Newspapers of 1927 and 1928 (Anon. 1927a; 1928a) each refer to two post offices, although a report (Anon. 1928b, 12) for 1927 indicates that the old one was pulled down in that year.

\section{THE ITALIAN POST OFFICE BUILDING}

Early in 1927 a totally new post office was built more than twice as far into the cave as the old one. Modern in style and quite large, with room for many tables outside beneath coloured glass

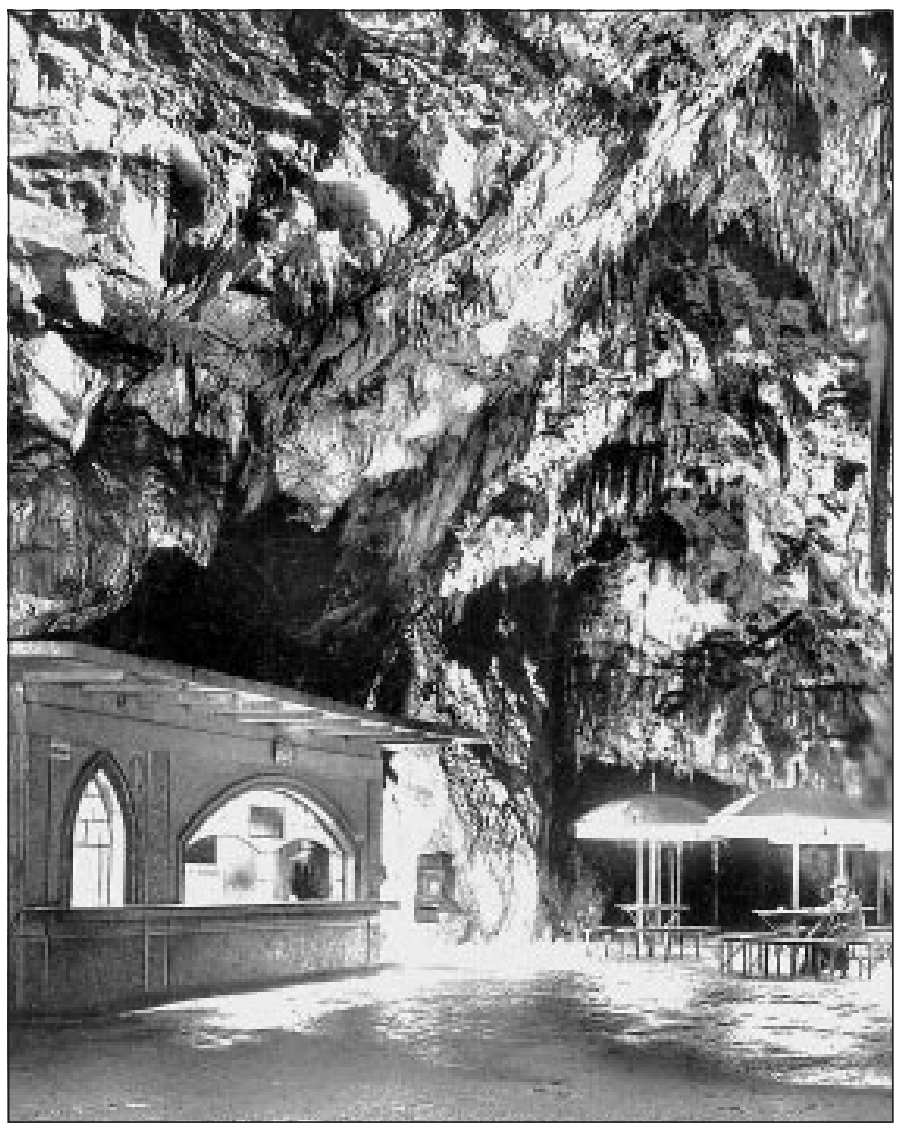
"umbrellas" (Fig. 12), it was built in the southeast corner of Koncertna dvorana (Fig. 13) not far from where today's visitors catch the cave train back to the surface after their tour. It was $1,4 \mathrm{~km}$ from the cave entrance (Fig. 3).

The year of its construction is commonly stated as 1926, for that is what is given by Perko \& Gradenigo $(1935,113)$, though they do not say this in the

Fig. 12: The post office opened in 1927 in Koncertna dvorana, showing a letter box on the far wall and some of the tables with glass umbrellas. 


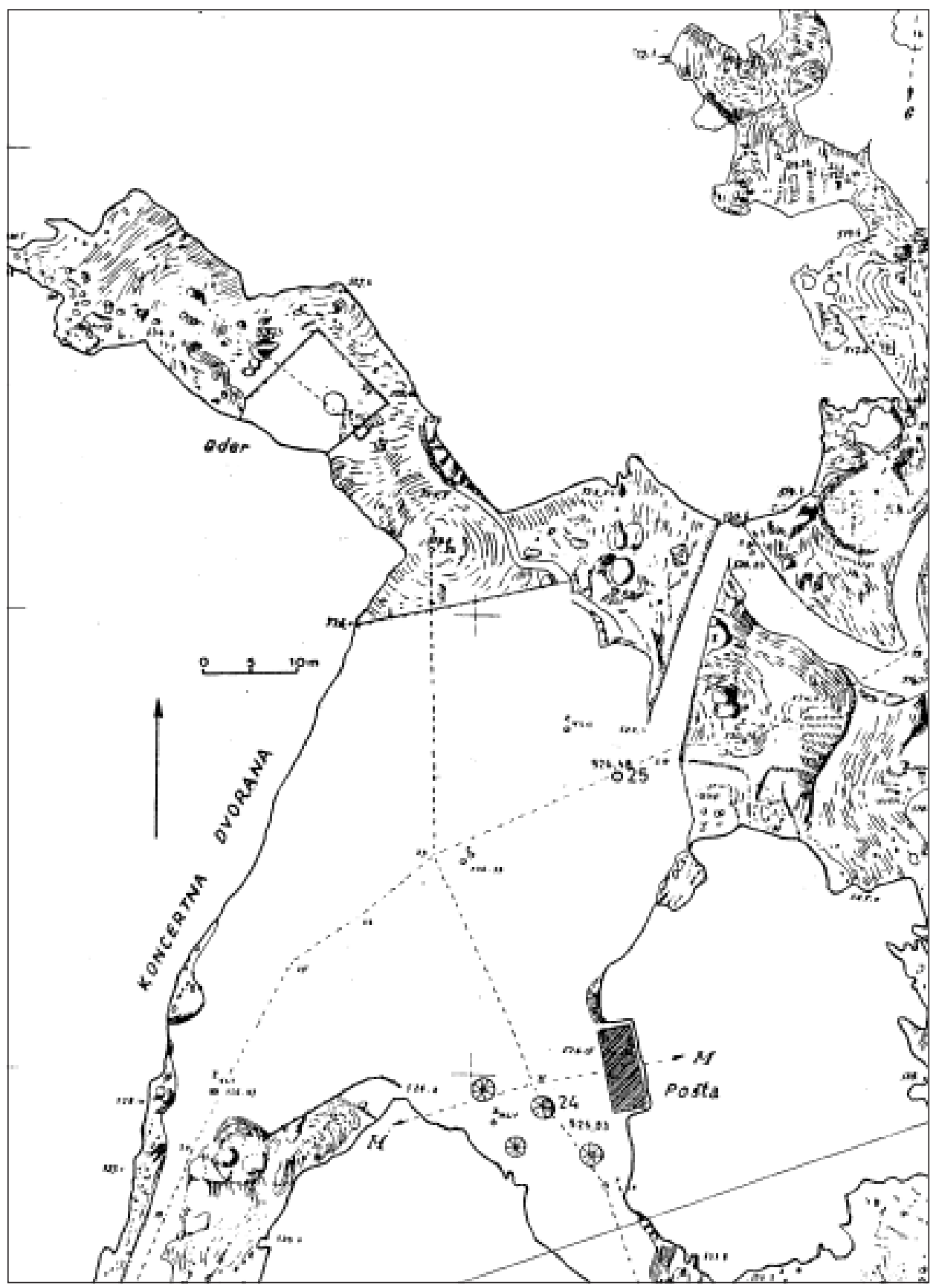

Fig. 13: Site of the 1927 post office ("Pošta") in Koncertna dvorana. Reissued in 1986 from a survey of c.1927-34. 
previous revised edition (1930) of their book. But not only has no reference to it been found in newspapers of 1926, there is positive evidence that it was still under construction during the winter of 1926/27, and its opening was reported in newspapers in the spring of 1927. Only the old post office is referred to in accounts (Anon. 1926a) of the May 1926 festival and in an announcement (Anon. 1926c) of the September one of that year. A statement in the minutes of the Cave Management Committee meeting held on 26 November 1926 (Postumia 1926, 11) reports that approval was given then for building the new post office. Direct evidence of its 1927 completion starts with the report of work (Anon. 1928c) at the cave in 1927 in which is mentioned finishing work in Koncertna dvorana including the new post office there. The earliest newspaper reference found to the new building is in a Ferrara newspaper (Anon. 1927b) of 8 May 1927. Another paper (Anon. 1927c) reports the formal opening of the new building as taking place on 16 May, and a later reprint of this (Anon. 1927d) reads as if the opening took place on 10 June. Dated postmarks are of no help in this case as the old post office remained in the use throughout than period. In any case, it seems certain from the evidence that the new building was open by the Whitsun festival of 5 June 1927. This is confirmed in a Trieste newspaper (Anon. 1927e) announcing the Whitsun festival: "on that day the new post office will start to operate."

An English language guidebook of the same year (Postumia 1927, 11) describes the place thus:

On the right [of the Concert Hall], a vast cavity opens on this fine hall: the Post Cavern... In a pretty construction, also unique in its way, the postal service of the R.R. Grottoes is carried on. All about, large umbrellas of colored glass, casting around a delicate light, invite the traveller to repose. From this point start daily thousands of postcards, with greetings from the unknown world.

Each of these glass umbrellas was positioned over a table at which ten people could sit to write the postcards they had bought (Perko \& Gradenigo 1930, 130-132).

Still increasing numbers of postcards posted at the festivals are reported for this time. At the Whitsun festival of 1927 the figure was 90.000

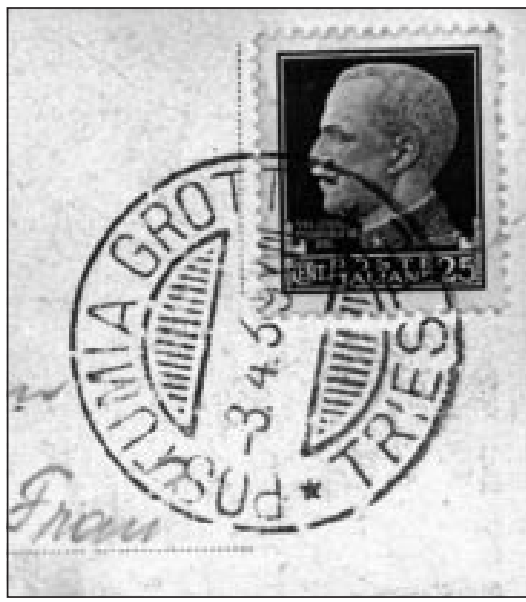
(Anon. 1927f). Perko $(1929,66)$ says that more than 70.000 were often posted at the festivals, while in 193080.000 was given as the normal figure (Perko \& Gradenigo 1930, 132).

It has already been mentioned that a new $28 \mathrm{~mm}$ postmark (Fig. 11) appeared in 1927. A larger one (31,5 mm diam.) (Fig. 14) was introduced in 1935 and remained in use until 1939.

Fig. 14: A new cave postmark introduced in 1935 (31,5 mm diam.). 


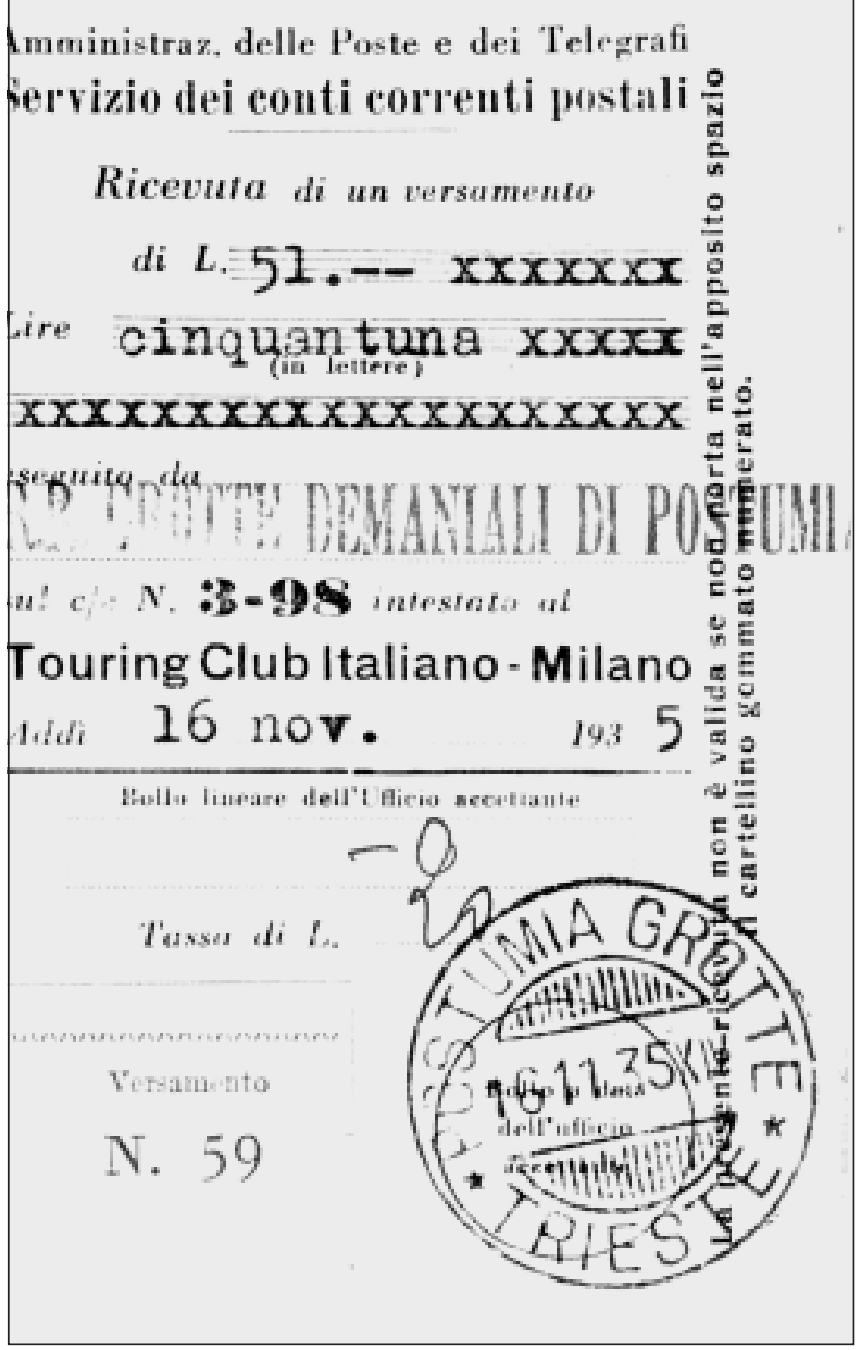

Fig. 15: The 1935 cave postmark used in the administrative building.

When the new building that now houses the Jamska restavracija was opened on 28 October 1928 (Anon. 1928c) it contained another post office as well as the station for the underground railway, the ticket office, cloakroom, administrative offices and the restaurant. The administrative office used the regular Postojna town postmark for its mail etc. up to the end of May 1935. From 1 June it used the same new $31,5 \mathrm{~mm}$ diameter "POSTUMIA GROTTE * TRIESTE *" postmark (Fig. 15) as the underground post office. It is likely that tourists' mail posted at this building received it too, making the true underground mail indistinguishable for the next few years.

\section{AFTER WORLD WAR II}

The Italian-built post office building survived for many years after World War II, but for most of this time it did not function as a post office.

When the cave was reopened to the public on 15 August 1945, a special new red cave postmark (Fig. 16) was used to cancel the first four stamps issued by the Jugoslav Military Government on that day for use in Zone B of the former Italian-occupied part of Slovenia - Slovensko Primorje and Istra and part of Notranjska (Michel 1997, 1573; Gibbons 1998, 575; Velikanje 2002, 108-109). A printed invitation to the event (Anon. 1945) notes that "For the reopening of 


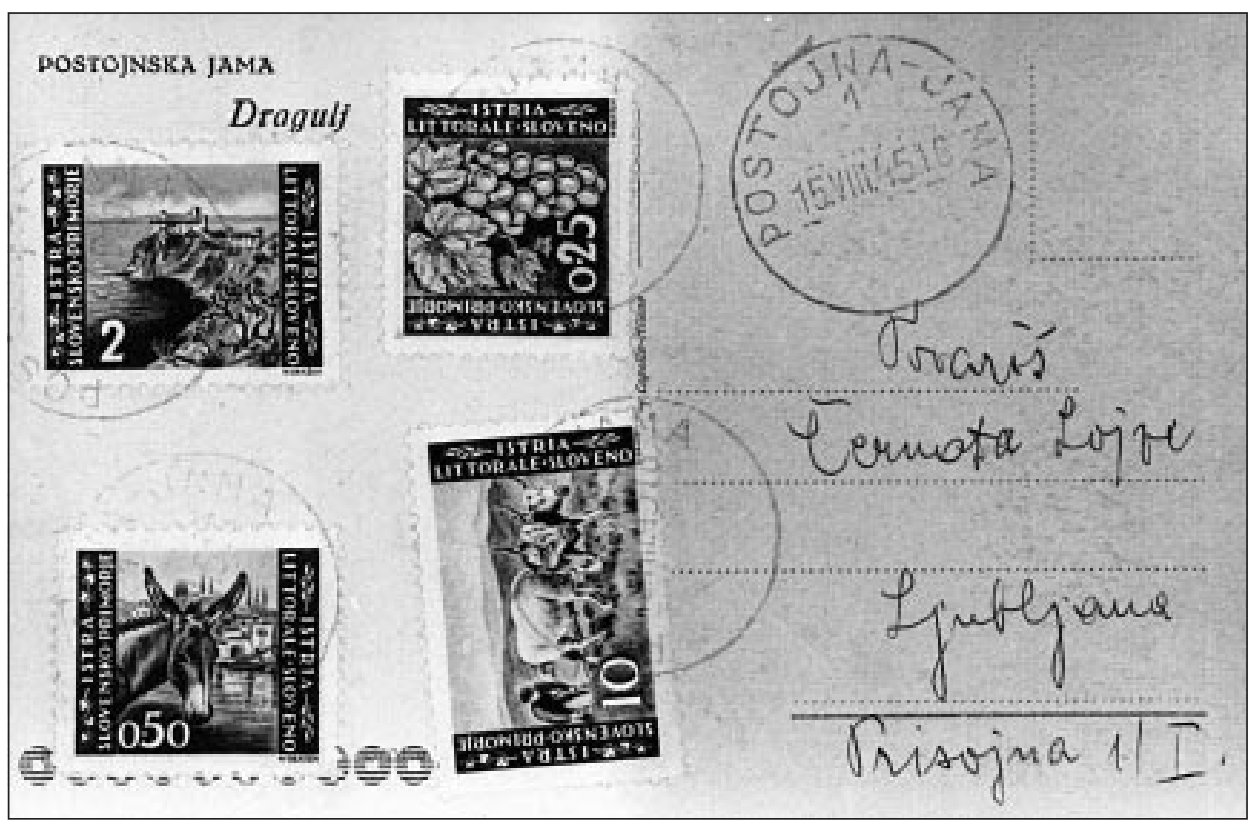

Fig. 16: A red postmark used on 15 August 1945 when the cave was reopened to the public after World War II.

the cave there will come into circulation four special stamps which will be stamped in the cave post office with a special postmark." Gorečan (1955) states that about 10.000 items were posted there on that day.

By 1952 the post office was in use, at least for the sale of postcards, whenever there was a concert in the cave (Šerko \& Michler 1952, 57) and by 1958 it operated throughout the tourist season, from 1 April to 30 October (Šerko \& Michler 1958, 62). This was still so when Šerko \& Michler $(1967,29)$ and Habe $(1977,49)$ specifically mention that mail was stamped with what they call a special postmark. It is likely that this was not an official post office cancellation but one of a succession of souvenir rubber stamps or cachets that were in use for many years. Certainly from 1962, when Marjan Šibenik became director and Albin Markovčič started work at the cave, there was, they both say, no underground post office.

Several later postmarks of Postojna mention the cave but only for publicity purposes as in modern slogan cancellations. The postmark in Fig. 17, known to have been used in 1954 and 1955, incorporates the normal circular town postmark and, despite additional lettering outside this ("Postojnska jama - biser podzemlja" [pearl of the underground]) and a picture of a proteus, it was probably not used underground. But without evidence we cannot be sure; perhaps someone who reads this may know.

The old Italian-built post office was finally demolished in February 1983, so that the present souvenir building could be erected before the tourist season began (Anon. 1983). 


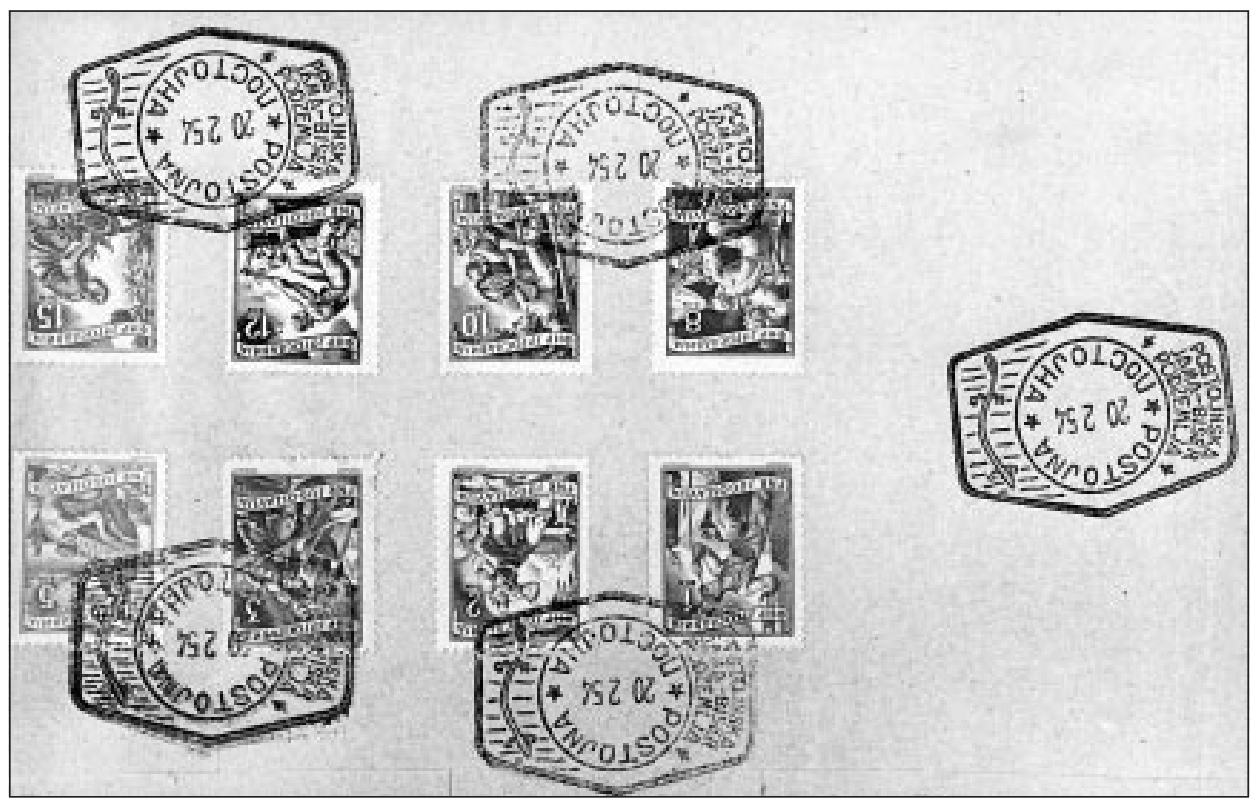

Fig. 17: A postmark known to have been used in 1954 and 1955.

\section{ACKNOWLEDGEMENT}

Nadja Adam of Notranjski muzej searched for, found and translated many of the newspaper accounts which provided dates and other important information.

Illustration credits:

Notranjski muzej, Postojna: 10

Goriški muzej, Nova Gorica: 4

archives of Postojnska jama: 5, 6, 8, 15

private collection: $1,9,12,14,16,17$

\section{REFERENCES}

Adelsberg, 1912: Weltberühmte Adelsberger Grotte.- Grottenkommission, p. 16, Postojna.

Anon., 1900: Das Pfingstfest in der Adelsberger Grotte.- Laibacher Zeitung, (128), 6 June, p. 1076, Ljubljana.

Anon., 1905: Upravno poročilo upraviteljstva Postojnske jame za leto 1904.- Upravna komisija Postojnske jame, p. 20, Postojna. 
Anon., 1911a: Ein originalles Postamt in der Adelsberger Grotte.- Österreichischer Illustrierte Zeitung, 16 August, Wien.

Anon., 1911b: Ein Postamt in der Unterwelt.- Neuigkeits Weltblatt, 2 July, Wien.

Anon., 1911c: Das unterirdische Postamt in der Adelsberger Grotte.- Illustrierte Kronen Zeitung, 4 August, Wien.

Anon., 1911d: Das Postamt der Adelsberger Grotte, das einzige unterirdische Postamt Europas.Bauern Zeitung, 19 August, Linz.

Anon., 1922a: Goriška straža, 31 May, Gorizia.

Anon., 1922b: Il Resto del Carlino, 7 September, Bologna.

Anon., 1923a: Le feste di Postumia e S. Canziano.- Le Vie d'Italia, 29, (7), 815, Milano.

Anon., 1923b: Il Popolo di Trieste, 31 August, Trieste.

Anon., 1924a: La sagra di Pentecoste fra gli incantevoli misteri del sottosuolo carsico.- Gazzetta di Parma, 16 June, Parma.

Anon., 1924b: La posta sotterranea nelle Grotte di Postumia.- Il Piccolo, 28 August, Trieste.

Anon., 1925: Relazione della Commissione alle loro eccellenze i ministri dell' economia e delle finanze sull' andamento dell' azienda durante l' esercizio 1924-1925.- Trieste, 47p.

Anon., 1926a: La festa di Pentecoste fra i misteri delle Grotte di Postumia.- Provincia di Como, 27 May, Como.

Anon., 1926b: La festa di settembre alle Grotte di Postumia.- L'Impero, 23 August, Roma.

Anon., 1296c: La festa nelle Grotte di Postumia.- Il Popolo di Trieste, 23 August, Trieste.

Anon., 1927a: La grande festa di settembre nelle Grotte di Postumia.- La Vedetta d'Italia, 25 August, Rijeka.

Anon., 1927b: Una sagra sotterranea a Postumia.- Corriere Ferrara, 8 May, 99 Ferrara.

Anon., 1927c: Nuovo ufficio postale nelle grotte di Postumia.- Gazzetta Azzurra, 24 May, Genova.

Anon., 1927d: Un nuovo ufficio postale nelle Grotte di Postumia.- Avvenire di Sicilia, 26 June, Palermo.

Anon., 1927e: Novice, 2 June, Trieste.

Anon., 1927f: 28.000 visitatori alla grande festa nelle Grotte di Postumia.- Corriere del Polesine, 7 June, Rovigo.

Anon., 1928a: I festeggiamenti di domenica nelle Grotte di Postumia.- Vedetta dell' Isonzo, 26 May, Gorizia.

Anon., 1928b: Relazione della Commissione alle loro eccellenze i ministri dell' economia e delle finanze sull'andamento dell'azienda dal 1 luglio 1926 al 31 dicembre 1927.- Postojna, $57 \mathrm{p}$.

Anon., 1928c: Nuove opere alle Grotte di Postumia inaugurate nell'annuale della marcia su Roma.Le Grotte d'Italia, ser.1, 2 (4): 177-178, Postojna.

Anon., 1945: Postojnski dnevi.- Arhiv Republike Slovenije, fond 278, Komite za turizem in gostinstvo LRS, a.e. 11, t.e.496 (copy in Notranjski muzej Postojna).

Anon., 1983: Pred turistično sezono bo v Koncertni dvorani Postojnske jame zgrajen nov sodoben trgovsko gostinski objekt.- Proteus Anguinus, 1, 4-5, Postojna. The month is stated as February in a work diary held by Postojnska jama management.

Banti, M.\&R., 2001: Speleophilately International, (62): 16, Schimmert.

Gibbons, S., 1998: Stamp catalogue Part 3 Balkans.- S. Gibbons, p. 695, London. 
Gorečan, I., 1955: Typescript by the director of the Postojna postal district, dated 7 July, in the archive of Notranjski muzej, Postojna.

Habe, F., 1977: The Postojna caves and other tourist caves in Slovenia.- Postojnska jama, p.82, Postojna.

Holzmann, H., A. Mayer, H. Raschko \& J. Wirth, 1992: Höhlenansichtskarten Niederösterreich 1 [Wissenschaftliche Beihefte zur Zeitschrift "Die Höhle" 40, Wien].

J[uvanec], F., 1910: Postojna, sloveča Postojnska jama in njena okolica.- M. Šeber, p.67, Postojna.

Lapajne, Š., [1907]: Aus der Chronik der Adelsberger Grotte.- Kleinmayr \& Bamberg, p.62, Ljubljana. Publication thus in pamphlet form may have occurred in 1907 or 1908; the contents first appeared in 1907 as a series of articles in the Laibacher Zeitung newspaper.

Michel, 1997: Europa - Katalog 1997/98, West, 1.- Schwaneberger, p. 1752, München.

Novak, D. (ed.), Gradivo za slovensko speleološko biografijo z bibliografijo.- Naše jame, 30 supplement, p.192, Ljubljana.

Perko, G. A., 1910: Die Adelsberger Grotte in Wort und Bild.- Komitee für den Bau eines internationalen Museums für Höhlenkunde in Adelsberg, p.78, Postojna.

Perko, G. A., 1929: Die Adelsberger Grotte in Wort und Bild.- Kgl. Grottenverwaltung, p.123, Postojna.

Perko, G. A. \& S. Gradenigo, 1924: Postumia ed il fantastico mondo sotterraneo delle sue celebri grotte.- Grotte di Postumia, p.192, vii, Postojna.

Perko, G. A. \& S. Gradenigo, 1930: Postumia ed il fantastico mondo sotteraneo delle sue celebri grotte.- Grotte di Postumia, p.204, Postojna.

Perko, G. A. \& S. Gradenigo, 1935: Postumia e le sue celebri grotte.- Grotte di Postumia, p.195, Postojna.

Postumia, 1926: Regie Grotte demaniali di Postumia. Verbale dell'adunanza del Consiglio d'Amministrazione tenuta in Postumia e Trieste addì 26 novembre. [Minutes of a meeting, in the archives of Postojnska jama]

Postumia, 1927: The royal government Caves of Posthumia Triest.- p.24, Roma.

P[utick], W., 1897: Führer in die Grotten und Höhlen sowie in die Umgebung von Adelsberg, Lueg, Planina, St. Canzian und Zirknitz.- R. Šeber, p.63, Postojna.

Rainer, H., 1995: Stempel-Handbuch der k.u.k. Feldpost in Österreich-Ungarn 1914 -1918.- p.400, Graz.

Šerko, A. \& I. Michler, 1952: Postojnska jama in druge zanimivosti krasa.- Turistično podjetje kraške jame Slovenije, p.166, Ljubljana.

Šerko, A. \& I. Michler, 1958: The cave of Postojna and other marvels of the karst.- $2^{\text {nd }}$ edn., revised.- Postojnska jama, p.187, Ljubljana [= Postojna].

Šerko, A. \& I. Michler, 1967: The Postojna grottoes and the other marvels of the karst.- Postojna, $58 \mathrm{p}$.

Union Postale Universelle, 1937: Dictionnaire des bureaux de poste.- $4^{\text {th }}$ edn.- Bureau Internationale de l'Union Postale Universelle, 2 vols., Berne.

Urbani, U. U., 1925: Postumia Romana.- M. Šeber, [18] p., Postumia.

Velikanje, J. \& M., 2002: Slovenika 2002 katalog poštnih znamk, celin in žigov.- p.117, ii, Ljubljana. 


\section{PODZEMNA POŠTNA URADA V POSTOJNSKI JAMI SLOVENIJA, 1899 - 1945}

\section{Povzetek}

Postojnska jama se je lahko pohvalila z edinstvenim podzemnim poštnim uradom (v določenem obdobju istočasno kar z dvema), kjer so prodajali znamke in razglednice in jih od tam tudi odpošiljali. Jamskim poštnim žigom lahko sledimo od leta 1899 do 1945. Tudi nekatere druge jame po svetu so imele svoje jamske poštne žige, vendar njihovi poštni uradi niso delovali v podzemlju.

Leta 1899 je avstrijsko trgovsko ministrstvo ugodilo prošnji jamske uprave. V jami so zgradili objekt, v katerem je lahko posloval podzemni poštni urad. Kamniti objekt je stal ob zahodni steni glavne poti, $35 \mathrm{~m}$ oddaljen od Kongresne oziroma Plesne dvorane in okoli $500 \mathrm{~m}$ od vhoda $\mathrm{v}$ jamo.

Nedvomno je poštni urad posloval 15. avgusta 1899 ob tradicionalni jamski veselici. To potrjuje poštni žig, odtisnjen tistega dne na razglednici. Žigov starejšega datuma ni. Sprva je poštni urad deloval le ob posebnih, množično obiskanih jamskih veselicah. Kasneje, gotovo pa po letu 1911, so obiskovalci svojo pošto lahko oddajali v poštni nabiralnik v jami, tudi ko poštni urad ni posloval. Po letu 1910 so ob poštnem uradu postavili tudi mize in klopi, kjer so obiskovalci lahko napisali razglednice.

Edinstveni podzemni poštni urad je za Postojnsko jamo pomenil svojevrstno mednarodno reklamo, saj se je njeno ime istočasno pojavilo v kar 18 časopisih v štirih različnih deželah (Francija, Nemčija, Češka in Avstrija).

Poštni urad je bil po končani prvi svetovni vojni ponovno odprt leta 1922. Postojnska jama je takrat pripadala Italiji in tako na poštnih žigih tistega časa namesto "Adelsberger-Grotte / Postojnska jama" zasledimo napis "Postumia (Grotte)". Število obiskovalcev je iz leta v leto naraščalo, zato so v začetku leta 1927 globoko v notranjosti jame, v Koncertni dvorani, skoraj kilometer in pol oddaljeni od vhoda, zgradili nov poštni urad. Sodobno, prostorno poslopje, pred katerim so stale številne mizice, je bilo zgrajeno na jugovzhodnem koncu Koncertne dvorane, nedaleč od mesta, kjer današnji obiskovalci ponovno vstopajo na jamski vlak, ki jih odpelje proti izhodu. Oba urada sta istočasno poslovala le nekaj mesecev, kajti proti koncu leta 1927 so staro poslopje pri Kongresni dvorani porušili. Poštni urad v Koncertni dvorani je redno posloval do leta 1939.

Poštni urad so porušili šele leta 1983. Vendar pa je funkcijo poštnega urada v vseh teh letih opravljal le enkrat. In sicer ob ponovnem odprtju Postojnske jame 15. avgusta 1945. Takrat je bil v uporabi nov, poseben rdeč jamski poštni žig, ki so ga odtisnili na štiri znamke, ki jih je tega dne za uporabo v coni B Julijske krajine (Slovensko primorje in Istra) izdala Vojaška uprava jugoslovanske armade (VUJA). 